\title{
Mevcut Binalarda Taşıyıcı Sistem Düzensizliklerinin Belirlenmesine Yönelik Bir Çalışma
}

\author{
Varol Koç ${ }^{1 *}$ \\ 1* Ondokuz Mayıs Üniversitesi, Mühendislik Fakültesi, İnşaat Mühendisliği Bölümü, Samsun, Türkiye, (ORCID: 0000-0003-4810-3845), kvarol@ omu.edu.tr
}

(İlk Geliş Tarihi 11 Ekim 2021 ve Kabul Tarihi 6 Aralık 2021)

(DOI: 10.31590/ejosat.1008230)

ATIF/REFERENCE: Koç, V. (2022) Mevcut Binalarda Taşıyıcı Sistem Düzensizliklerinin Belirlenmesine Yönelik Bir Çalışma. Avrupa Bilim ve Teknoloji Dergisi, (33), 32-39.

$\ddot{O} \mathbf{z}$

Yapıların deprem davranışları geçmişte ve günümüzde çokça araştırılmış ve araştııılmakta olan bir konudur. Depremsel davranış açısından yapısal düzensizliklerin ağır hasarlara ve göçmelere sebep olabildiği bilinmektedir. Binanın depreme karşı dayanımlı olabilmesi, sistem düzensizliklerinin az olmasına doğrudan bağlıdır. Örneğin düzensizliklerin en yaygın ve önemlilerinden biri olan yumuşak kat düzensizliği, katlar arasında rijitlik farklılıkları oluşması nedeniyle, bu düzensizliğin görüldüğü yerlerde göçmeler meydana getirebilir ve genelde yapıların ilk katlarında görülür. Türkiye Bina Deprem Yönetmeliği’ne göre, sadece planda düzensizlik durumlarından başlıcaları şöyledir: Burulma Düzensizliği, Döşeme Süreksizlik Düzensizliği, Plan Geometrisi Düzensizliği, Taşıyıcı Eleman Eksenlerinin Paralel Olmaması Durumu (Ortogonal Olmama Düzensizliği).

Bilindiği üzere topraklarının yarısından çoğu deprem bölgesinde bulunan Türkiye'de, geçmiş yıllarda birçok deprem meydana gelip kalıcı hasarlar bırakmıştır. Bu hasarların sebeplerinden bazıları, yanlış yer seçimi, bilgi- tecrübe eksikliği, düşük maliyet isteği, yapılacak olan yapının hızlı bitmesinin istenmesi ve tasarımcılar arası iletişimin yetersizliğidir. Bazen deprem bölgelerinde yaşanan depremlere duyarsız kalınıp, yıkılan binaların yerine mevcut ve benzer tekniklerle ve hemen hemen aynı tasarımlar ile yeni binalar yapılmaya devam edilmiştir. Deprem konusu hafife alınmayacak kadar önemli olduğundan, bütün toplumun bilinçlendirilmesi gerekmektedir. Topluma, temel düzeyde de olsa, yapı düzensizlikleri konusunda bilgi kazandırılabilir ve bu da, yapılacak yapılar için mimari düzensizliklerden kaçınmaya yönelik tasarımlar yapılması yönünde zorlayıcı bir neden oluşturabilir. Deprem güvenli bir yapı için; deprem güvenli mimarlık anlayıșı olmalıdır. Zira inşa edilecek yapı, ilk olarak tasarlanmalıdır. Tasarımın alt yapısı ise öncelikle mimarlık ve mühendislik müfredatında depreme yönelik tasarım dersinin ayrı ve zorunlu bir ders olarak katılması ve ders içeriklerinin iyileştirilmesi ile sağlanacaktır.

Yanlış kentleşme, çevre düzenine uyulmaması, binaların bitişik nizam inşası, gereğinden fazla düzensiz ve büyük yapılması, hasarları artıran etkenlerdendir. Yıkıcılık etkisi en büyük olan sığ deprem çeşidi, ülkemizde en fazla görülen deprem türüdür. Dolayısıyla ülkemizde düzensiz tasarımlardan kaçınmak mantıklı olacaktır. Bu bilgilerin ışığında bu çalışmada, Türkiye'de mimari olarak düzensiz binalara eğilimin ne oranda olduğunu küçük çaplı bir araştırma ile ve belli hatlarıyla anlayabilmek için, Samsun ili Atakum ilçesinde 420 adet bina, gözlemsel metod ile incelenmiş ve uygulamadaki mevcut düzensizliklerin çeşitleri belirlenmeye çalışılmıştır.

Anahtar Kelimeler: Betonarme yapılar, Taşıyıcı sistem, Depreme dayanıklı yapı tasarımı, İstenmeyen düzensizlikler, Mimari tasarım, Gözlemsel bina incelemesi, Depremsel yapı davranışı

\footnotetext{
*Sorumlu Yazar: kvarol@ omu.edu.tr
} 


\title{
A Study on the Determination of Structural System Irregularities in Existing Buildings
}

\begin{abstract}
The seismic behavior of buildings is an important issue that has been frequently researched in the past and today. It is known that structural irregularities can cause severe damages and collapses in terms of the behavior of structures under the effects of the earthquake. The earthquake resistance of the building is directly dependent on the minority of the system's irregularities. For instance, soft-story irregularity, which is one of the most common and important irregularities, may cause collapses in the floors where this irregularity is observed, due to the formation of stiffness differences between floors, and it generally occurs in the first floors of buildings. According to the Turkish Building Earthquake Code, the main irregularities in the plan are as follows: Torsional Irregularity, Slab Discontinuity Irregularity, Plan Geometry Irregularity, Structural Element Axes Not Parallel (Non-Orthogonal Irregularity).
\end{abstract}

As it is known, in Turkey, more than half of its territory is located in the earthquake zone, many earthquakes have occurred in the past years and left permanent damage. Some of the reasons for these damages are wrong location selection, lack of knowledge-experience, low-cost demand, desire for the construction to be completed quickly, and insufficient communication between designers. Sometimes, insensitive to earthquakes in seismic zones, new buildings continued to be built using existing and similar techniques and almost the same designs, instead of demolished buildings. Since the earthquake issue is too important to be taken lightly, it is necessary to raise the awareness of the whole society. Even at a basic level, the society can be informed about building irregularities, and this can create a compelling reason for designs to avoid architectural irregularities for the buildings to be built.

For an earthquake-safe structure; there should be an understanding of earthquake-safe architectural design because the building to be built must first be designed. The infrastructure of the design will be provided by including the earthquake design course as a separate and compulsory course in the architecture and engineering curriculum and improving the course content.

Incorrect urbanization, non-compliance with the environmental order, construction of buildings adjacent to each other, the construction of buildings too large and irregular are among the factors that increase the damage. The shallow earthquake type, which has the greatest destructive effect, is the most common type of earthquake in our country. Therefore, it would be logical to avoid irregular designs in our country. In the light of this information, in this study, 420 buildings in the Atakum district of Samsun province were examined with the observational method and the types of irregularities in practice were tried to be determined to understand the extent of the tendency towards architecturally irregular buildings in Turkey with small-scale research.

Keywords: Reinforced concrete structures, Structural system, Earthquake resistant structure design, Undesirable irregularities, Architectural design, Observational building investigation, Seismic structural behavior

\section{Giriş}

Ülkemizdeki mevcut yap1 stoğunun genelde deprem davranışı açısından kötü olduğu ve büyük tehlike oluşturduğu düşünülmektedir. Yapısal düzensizliklerin önceden belirlenmesi yapısal davranışın tahmini açısından önemlidir. Yapısal düzensizliklerin bulunduğu yapıların çoğunun yüksek katlı olması da büyük bir sorun teşkil etmektedir (Korkmaz ve Uçar, 2006). Zira günümüzde artan nüfus ve gelişen teknolojiyle birlikte kentlerde yüksek yapılar hızla artmaktadır. Bu yapıların mimari tasarım süreçleri ve beraberinde oluşturulan taşıyıcı sistemleri, yapıların önemli noktalarını meydana getirmektedir. Yapılarda mimari tasarım ve taşıyıcı sistem tasarımları yapılırken deprem olgusu önemli bir yer tutmalıdır. Yapılar yapılırken rüzgar, deprem, yangın, malzeme seçimleri gibi dikkat edilmesi gereken bazı noktalar vardır ve bu noktalar 1şığında taşıyıcı sistemleri de oluşturulmaktadır. Özellikle yüksek yapıların tasarımındaki en önemli konu taşıyıcı sistemin doğru seçilmesidir. Taşıyıcı sistem hem binanın kendi ağırlığını hem içindeki eşya ve insanların ağırlığını hem de sonradan oluşabilecek deprem, rüzgar gibi faktörleri en iyi şekilde karşılamalıdır. Özellikle nispeten yüksek olan yapılar, depremsel davranışta hali hazırda zaten bir takım düzensizlikler oluşturacağı için, bunlar göz önüne alınarak tasarım yapılması gerekmektedir.
Ulusoy ve Güven (2019), dünyanın farklı bölgelerinden seçilen yüksek yapıların herhangi bir hesaplama yapılmaksızın sadece erişilebilen kat planları ve yapı geometrilerinin planda düzensizlik durumlarına göre incelemelerini yapmışlardır. İncelenen binalar, Burj Khalifa, Marina 101, Mahanakhon (King Power), Damac Heights, JW Marriott Marquis Otel binalarıdır. Sonuç olarak, toplamda 2 adet yapıda burulma düzensizliği, 1 adet yapıda döşeme süreksizlik düzensizliği, 2 adet yapıda plan geometrisi düzensizliği ve 3 adet yapıda taşıyıcı eleman eksenlerinin paralel olmaması durumu tespit edilmiştir. Ancak bahsedilen yapılar üstün mühendislik ve işçilik hizmetlerinin yapıldığı, yüksek kalitede taşıyıcı sistem malzemelerinin kullanıldığı yapılardır. Depremselliği nispeten düşük bölgelerde ve yine nispeten güçlü zeminler üzerindedir. Bu yapılardakine benzer ve hatta çok daha çeşitlilikte düzensizliklere, sıradan yapılarda, hem de zayıf zeminde ve deprem riski yüksek bölgelerde de yaygın olarak karşılaşılmaktadır. Bu durum, üst seviye malzeme ve hizmet desteği almamış binalar için deprem güvenliğini önemli ölçüde düşüren bir etkendir.

Düzensizlikler ve depremler sonrası ağır hasarlar üzerine yapılmış incelemeler sonucunda elde edilen verilerin, yapı tasarımı yapacak olan mimar ve mühendislere veri oluşturulması gerekir. Bununla birlikte, bina yapılırken birçok meslek grubu, iç içe bir dayanışma ve fikir alışverişine açık olarak, yapıda oluşabilecek deprem etkisini en aza indirgemeyi hedeflemelidir. Türkiye'de önemli ve yoğun depremler olmasına rağmen, halen 
Üniversitelerin ilgili bölümlerinde deprem ile ilgili dersler, genelde ana ders üzerinden verilmektedir. Çoğunlukla lisans ve lisansüstü programlarda seçmeli ders olarak sunulmaktadır. Bu durum, dersin önemini öğrenci gözünde de düşürmektedir. Depremin yapılar üzerindeki etkileri ve uygun taşıyıcı sistem tasarımına yönelik ilkelerin, ilgili bölümlerde ana ders olarak verilmesi ve öğrencilerin bu konu hakkında bilinçlendirilmeleri gerekmektedir. Mimarların bu ders hakkında yeterli bilgiye sahip olmamaları ve proje üzerinde bu konu hakkında inşaat mühendisleri ile olması gereken iletişim eksikliği, önemli sorunlar arasındadır (Ayyıldız ve Özbayraktar, 2005).

Akçaner ve Özdemir (2015), Türkiye'deki bazı üniversitelerde verilen mimarlık eğitiminin ne derece taşıyıcı sistem davranış bilgisi içerdiğini araştırılarak ABD ve Japonya mimarlık eğitimleri ile kıyaslamış ve bunun sonucunda Türkiye'deki mimarlık eğitiminin yetersizliklerini saptamışlardır. Söz konusu çalışmada mimarlık eğitiminin sorgulanmasının sebebi, Türkiye'de meydana gelen depremlerin acı sonuçları ve bu depremlerdeki kayıpların oluşmasında mimarı tasarım hatalarının da payının bulunuyor olmasıdır. Çalışma toplamda 8 bölümden oluşmaktadır. Öncelikle mimarlığın tanımı ve önemi irdelenmekte, ardından depreme dayanıklı yapı tasarımında önemli noktalar incelenmekte, sonraki bölümlerde ise Türkiye'deki, ABD'de ki ve Japonya'da ki üniversitelerin taşıyıcı sistemle ilgili verdiği dersler karşılaştırılmaktadır. Son kısımda ise tüm bu bulgulara dayanarak mimarlık bölümündeki eğitim ve öğretimin eksiklikleri, yanlış olan noktaları değerlendirilmektedir. Çalışmanın sonucunda, taşıyıcı sistem bilgisi derslerinin toplam dersler içindeki oranı, bazı üniversite bölümlerinde yeterli, bazılarında yetersiz olarak belirlenmiştir. Türkiye'nin her yerinde eşit mimarlık eğitiminin verilememesinin öğretim kadrosundaki eksikliklerden kaynaklandığı saptanmıştır.

Deprem mühendisi ile iş birliği içinde gerçekleştirilmiş bir tasarımda, sismik izolasyon konusu, pasif ve aktif kontrol yöntemleri, karma izolasyon sistemleri de ayrıca araştırılması ve üzerinde durulması gereken konular olabilir. Yapıya yerleştirilmiş enerji sönümleyici pasif sistemlerin olmaması durumundaki binalar veya daha yaygın olarak kullanılmayan aktif sistemlere sahip olmayan yapılar, şiddetli depremler sırasında elastik sınır ötesinde yer değiştirme yaparlar ve kalıcı deformasyon yapabilme yetenekleri ölçüsünde ayakta kalırlar. Sonuçta, depremde yapılar; hafif, orta veya ağır hasarlar alırlar. $\mathrm{Bu}$ gibi hataların oluşmaması, binaların en ufak bir sarsıntıda yıkılmaması için mimar ve mühendislerin üzerine de birçok görev düşmektedir. $\mathrm{Bu}$ yüzden mimar ve mühendis, bu konularda birçok araştırma yapmalıdır. Bunlardan en önemlisi ise, uygulanacak projenin zemininin genel jeolojik ve jeofizik özelliklerinin bilmesi, afet bölgelerinde uyulması gereken kurallara ve yönetmeliklere uyulmasıdır (Akıncıtürk, 2000).

Binaların taşıyıcı sistem düzensizliği yanında, beton ve donatı sorunları, depremler sonrası hasarların en büyük nedenidir. Beton, çimento, iri - küçük agrega, su ve gerektiğinde katkılardan oluşan bir malzemedir. Betonarme ise beton ve çeliğin birlikte kullanılmasıyla oluşan bir yapı malzemesidir. Betonarme diyebilmek için beton ve çeliğin birlikte çalışması yani aderansı sağlanmalıdır. Betonda bulunan boşluklardan dolayı su beton içerisine girebilmekte ve hem betonun hem de çeliğin korozyonuna sebep olup performans kaybına yol açmaktadır. Bu kayıpların en önemlileri donatının kesit alanında, mekanik ve aderans performansında azalmalardır. Ayrıca çimento hamuru ile agregalar arası aderans da olumsuz e-ISSN: 2148-2683 etkilenmekte, beton bütünlüğü bozulmakta, beton harcı içinde kılcal çatlaklar oluşup gelişmektedir. Durabilite, hava koşulları, kimyasal etkiler ve diğer koşullarda yapının özelliğini koruması olarak tanımlanabilir. Dayanım, dayanıklılık ve işlenebilirlik betondan beklenen özelliklerdir. Beton taze iken şekil verilebilmesi ve kıvamı ne kadar önemliyse donmuş betonun servis ömrü ve dayanımı da o kadar önemlidir. Beton veya betonarmede bulunan su ve nem, bozulmaya sebep olabilir. Betona nüfuz eden su, zararlı maddelerin de taşınmasına sebep olarak betonu aşıp çeliğe ulaşabilir. Betondaki boşluklar bu duruma zemin hazırlar. Betonun ve çeliğin birlikte kullanılmasını mümkün kılan başlıca sebepler, eşit ısıl genleşme katsayıları, aderans ve betonun çeliği korozyondan korumasıdır. Beton, kimyasal korozyondan dolayı, donatıy pasif koruyuculuğu özelliğini yitirir. Bunun sonucunda beton- donatı ara yüzeyinde oluşan korozyon ürünleri, içsel gerilmelere sebep olur. Donatıda meydana gelen paslanma, donatının hem servis ömrünü hem de dayanımını olumsuz etkiler (Koç, 2016b).

Betonarme çeliğinin korozyonuna sebep olan başlica faktörler; malzeme, üretim süreci, kullanım süresince karşılaştığ1 durumlar ve ortamlardır. Korozyon deneyleri, hızlandırılmış korozyon deneyi ve doğal korozyon deneyi şeklinde yapılabilir. Numunelerin korozyona uğramış olması monolitik yükleme deneylerinde süneklik oranları ve enerji yutma kapasitelerinde önemli veriler sağlamaktadır. Deniz suyuyla doğrudan ya da dolaylı temas, durabilite sorununa sebep olmaktadır. Betonun korozyon- aderans ilişkisini belirlemede; klorür geçirimliliği, su emme, su geçirimliliği, kılcal su emme deneyleri belirleyici sonuçlar sağlamaktadır. Korozyon ile ilişkili olan kılcallık katsayısında, su kürü uygulanan ve uygulanmayan numuneler üzerinde beş kata kadar fark bulunmaktadır. Özellikle deprem sonrası hasarlı yapılarda donatı korozyonuna bağlı aderans, durabilite ve buna bağlı büyük kesit kayıplarının yaşanması, donatı korozyonunun yıkımlarda başrol oynadığının bir göstergesidir. Beton, standartlara uygun olarak üretildiğinde donatıy1 korozyondan korumak için yeterlidir. Betonarme donatısında oluşan korozyon, betonda çatlama ve dökülmelere, aderans ve performans kayıplarına, donatının mekanik özelliklerinde olumsuz değişmelere sebep olabilmektedir. Korozyonun oluşturduğu en büyük tehlikelerden birisi, elemanlar ve sistemin davranışında değişikliklere sebep olmasıdır. Korozyonun sebep olduğu performans kaybının iyileştirilmesinde sanayi atığı maddelerin belirli oranlarda bağlayıcı olarak kullanılması, yeni nesil yöntemlerle yapılabilir. Betonda kullanılan malzeme türü, kür uygulanıp uygulanmaması, pas payı, bulunduğu ortam vb., betona gömülü donatının korozyonunu büyük ölçüde etkilemektedir. Yapının temelinde bulunan donatıların korozyon hesabından yola çıkılarak yapının ekonomik ömrünün hesaplamasına yönelik çalışmalar yapılmaktadır (Doğan ve Akgül, 2020).

\section{Materyal ve Metot}

Beton ve donatının kalite ve yerleştirim sorunları ile her iki malzemeye yönelik oluşan korozyon etkisi, depreme dayanıklı yapılar için yüksek oranda önemli olumsuz durumlar olmakla birlikte, yapının mimari tasarımının ve buna uygun olarak düzenlenen taşıyıcı sisteminin temel düzensizliklerden elden geldiğince uzak olabilmesi, deprem etkilerinin yapı tarafından rahat tölere edilebilmesi açısından büyük önem taşımaktadır (Koç, 2021d). Üst düzey mühendislik, kalifiye işçilik ve kaliteli malzeme kullanımı ile, çok aşırıya kaçmayan mimari düzensizlikleri, deprem açısından önemli sorunlar 
oluşturmayacak şekilde uygulayabilmek mümkündür. Ayrıca özellikle sağlam zeminlerde ve düşük deprem riskine sahip bölgelerde yapılan yapılarda da, mimari düzensizlikler büyük önem arzetmeyebilir. Ancak tüm bu kriterlerin tam olarak sağlanamadı̆̆ı normal piyasa yapılarında, söz konusu düzensizlikler her zaman için sorun oluşturabilecek durumlardır. Sıradan mühendislik, işçilik ve malzeme kullanımlarında, elden geldiğince bu tür düzensizliklerden kaçınmak, yapının depremsel davranışının sağlıklı olabilmesi açısından tercih edilmesi gereken seçenekler olmalıdır. Bununla birlikte, genel olarak çoğu yapıda, mimari düzensizliklerle, şu ya da bu şekilde sıklıkla karşılaşılmaktadır. Taşıyıcı sistemi etkileyen mimari düzensizlikler, belli başlı 12 grup halinde sınıflandırılmış ve Tablo 1.'de sunulmuştur (Koç ve Tuhta, 2012a ,b; Koç, 2016a, b).

Düzensizliklerin tercih edilme oranlarını tespite yönelik olarak, daha önceki çalışmalara benzer şekilde (Koç, 2021a, b, c), Samsun ili Atakum ilçesi Deniz evleri mahallesinde 420 adet bina, gözlemsel metodla incelenmiş ve her binada hangi düzensizliklerin olduğu tespit edilmiştir. Düzensiz binalara ait, sahadan alınan bazı örnek fotoğraflar, ait oldukları düzensizlik numaraları ile birlikte, Şekil 1 ve 2.' de verilmiştir.

Tablo 1. Düzensizlik tipleri ve numaralarl (Table 1. Irregularity types and numbers)

\begin{tabular}{l|l}
\hline $\begin{array}{l}\text { Düzensizlik } \\
\text { No }\end{array}$ & Düzensizlik Tipi \\
\hline 1 & Kolon -perde rijitliklerinin planda x ve y yönünde düzgün dagıtılmaması \\
\hline 2 & Süreksiz kiriş - kolon -perde \\
\hline 3 & Asma kat ve/ veya yüksek giriş \\
\hline 4 & Yumuşak kat \\
\hline 5 & Kısa kolon \\
\hline 6 & Zayıf kolon kuvvetli kiriş etkisi \\
\hline 7 & Cephe boşlukları, yatayda- düşeyde asimetri ve/ veya girinti- çıkıntı \\
\hline 8 & Bitişik nizam \\
\hline 10 & Çıkmalı yapıda konsol uç kolon ve/ veya kirişi \\
\hline 11 & Saplama kiriş- saplamanın saplaması \\
\hline 12 & Yan kirişsiz balkon döşeme ve saçaklar \\
\hline
\end{tabular}
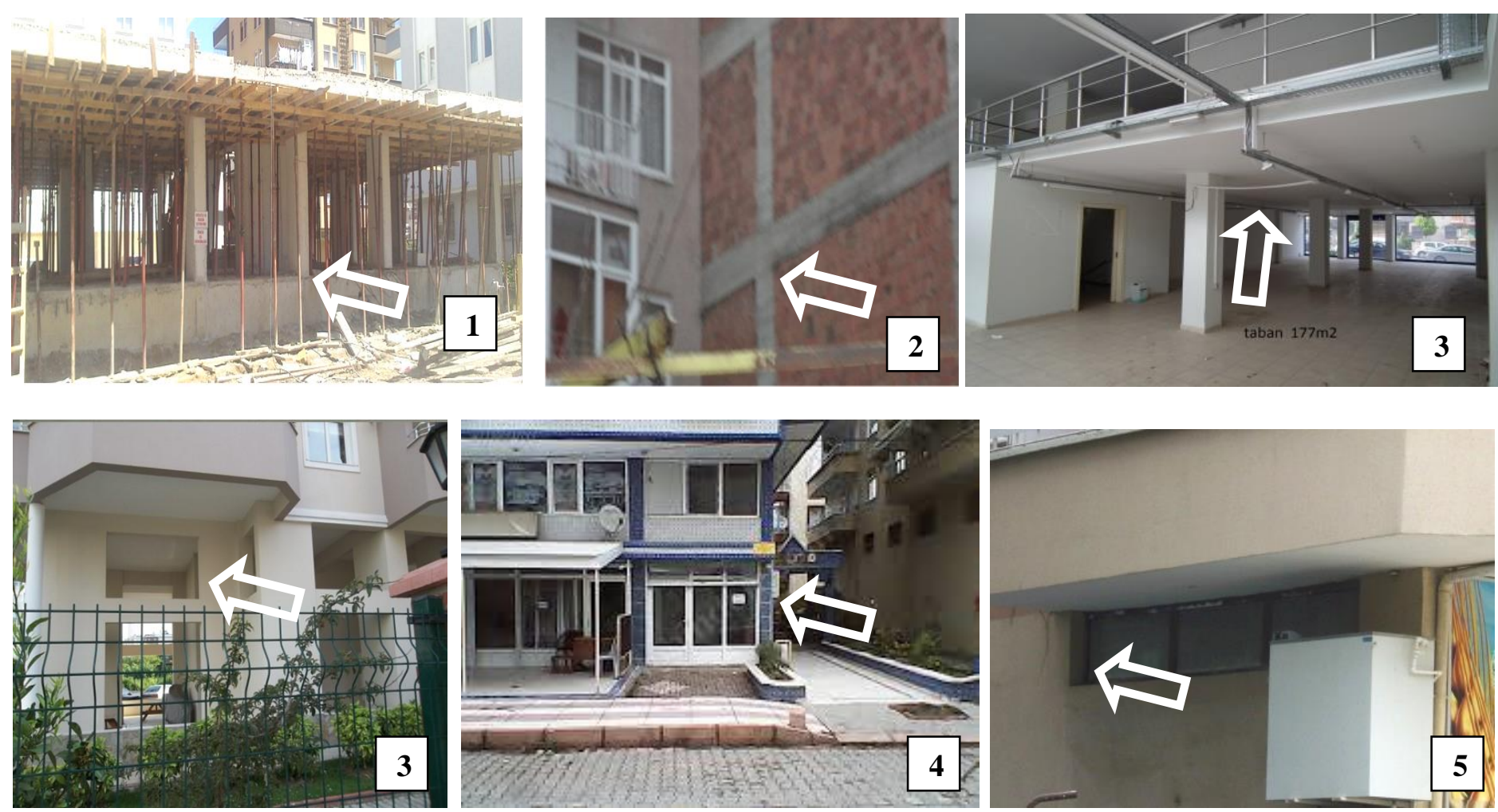

Şekil 1. Sahadan düzensizlik örnekleri ( 1 - 5 nolu düzensizlikler) (Figure 1. Examples of irregularities from the field (Irregularities 1 to 5)) 

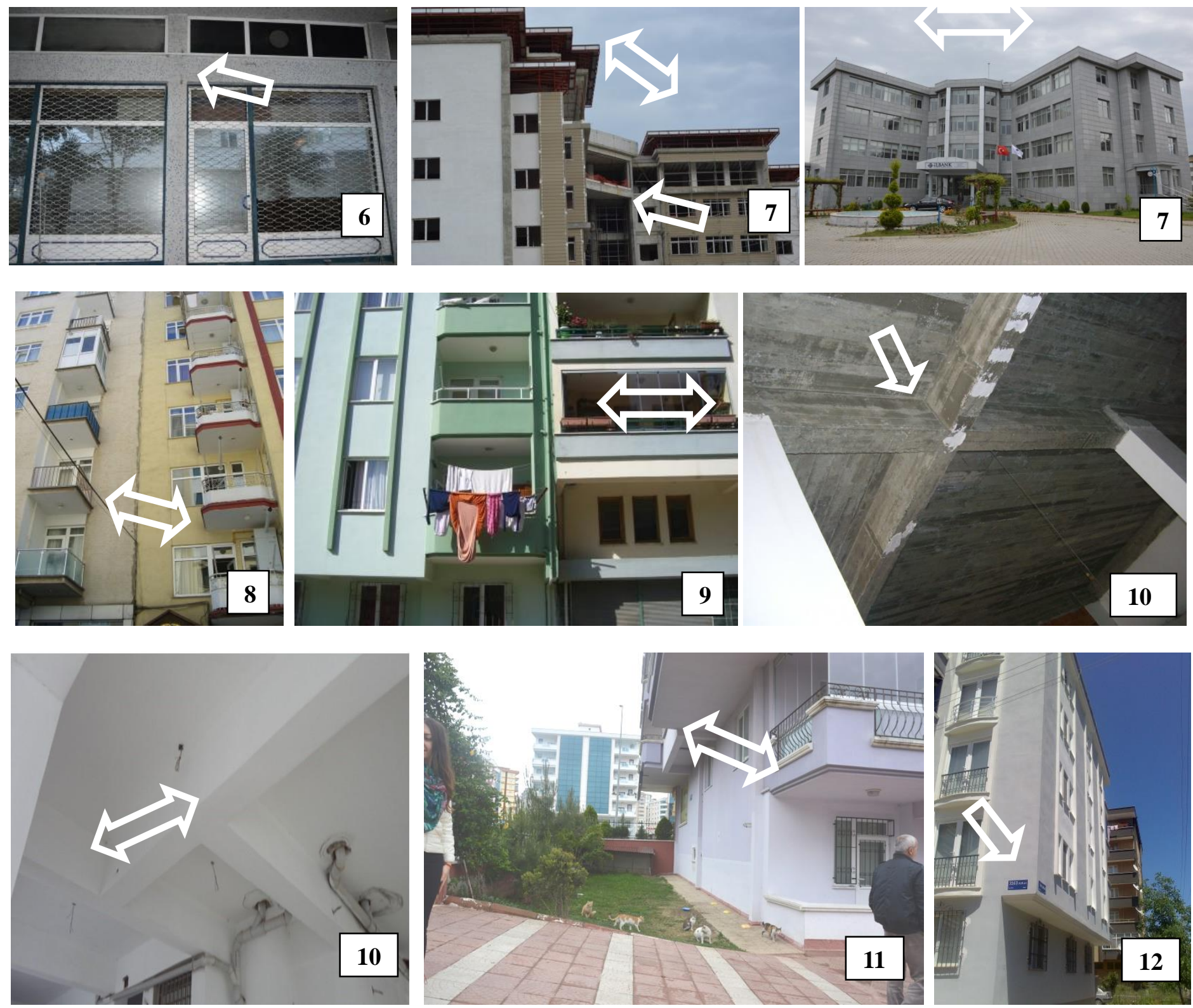

Şekil 2. Sahadan düzensizlik örnekleri ( 6- 12 nolu düzensizlikler) (Figure 2. Examples of irregularities from the field (Irregularities 6-12))

\section{Araştırma Sonuçları ve Tartışma}

Söz konusu alanda 420 binanın, sadece gözlemsel incelenmesi ile tespit edilebilen düzensizlikler, yatay eksen, Tablo 1'de verilen düzensizlik numarasını, düşey eksen, düzensizliklerin kaç adet binada görüldüğünü gösterecek şekilde sinıflandırılarak Şekil. 3'de verilmiștir. Buna göre, incelenen alanda en çok, asma kat ve/ veya yüksek giriş (420 binada 96 adet) ile, yan kirişsiz balkon, döşeme ve saçak (420 binada 88 adet) düzensizlikleri tespit edilmiştir. Bazı yapılar asma katsız ancak yüksek girişli, bazıları da hem asma katlı hem yüksek girişlidir. Bazı yapılarda asma kat kirişleri yapılmış durumda olup, döșeme imal edilmemiş, bu durumda olan bazı binalarda da, sonradan betonarme harici (çelik ve ahşap) platform döşemeler kullanılmışırı. Tüm bu benzer ve ilişkili düzensizlik durumlarının, genel bütünsel yaklaşımdan uzaklaşmamak adına, ayrı ayrı numaralandırılıp sonuçlara yansitılması yerine, temel e-ISSN: $2148-2683$ bir düzensizlik sınıfı olarak değerlendirilmesi uygun görülmüştür. $\mathrm{Bu}$ noktada belirtilmelidir ki, gözlemsel incelemelerde, yapıda sadece ve özellikle giriş katlarında bölme duvar kaldırılması durumuyla oluşan yumuşak kat düzensizlikleri, 4 nolu Yumuşak kat düzensizliklerine işlenmiştir. Asma kat ve/ veya yüksek giriş düzensizliğinde ( 3 nolu) gelende dış duvarların camekan ve iç duvarların kaldırılmış olma durumu söz konusu olduğundan, bu düzensizlik aynı zamanda yumuşak kat düzensizliği de oluşturmaktadır. Ancak 4 nolu düzensizliğe, asma kat ve/ve ya yüksek girişi olmayan, sadece duvar kaldırma uygulaması görülen yapılar; 3 nolu düzensizliğe de diğerleri işlenerek, çakışık durumların birden çok kere işlenmesi engellenmiştir.

Yan kirişsiz balkon, döşeme ve saçak düzensizliği ise, özellikle 20 yıllık ve daha eski yapılarda, düz betonarme döşemenin büyük ya da küçük bir çıkma oluşturacak şekilde konsol döşeme olarak sürdürülmesi ile meydana gelmiştir. $\mathrm{Bu}$ 
yapılar, konsol döşemenin yan bölümlerinden ve konsol döşeme genişliği ve taşıyıcı sistemin sürekliliğine göre gerekirse orta bölümlerinden konsol kiriş desteği almamış yapılardır. Genelde nispeten daha yeni yapların bir kısmında da, dişli döşemenin konsol olarak devam ettirildiği, ancak yine bahsedilen türde ana kiriş desteklerinden mahrum bırakıldığı tespit edilmiştir.

Şekil 4'de her bir düzensizliğin toplam yüzdelik düzensizlik pastasında, ne oranda tercih edilmiş olduğu gösterilmiştir. Buna göre, üst paragrafta bahsedilen düzensizlikler, toplam düzensizlikler arasında sirasıyla $\% 17$ ve $\% 15$ oranlarında görülmekte, bunları \%13 ile yumuşak kat, \%12 ile cephe boşlukları, yatayda- düşeyde asimetri ve/ veya girinti- çıkıntı oluşturulması düzensizlikleri takip etmektedir. Yine \%12 ile, çıkmalı yapıda konsol uç kolon ve/ veya kiriş konulması düzensizliği de gözlenmiş durumdadır. Yukarıda da bahsedilen bütünsel yaklaşım gereği, benzer nedenlerden kaynaklanıp benzer sonuçlar üreten, binada cephe boşluğu olması, planda ya da cephede asimetrik veya girintili çıkıntılı yapı düzenlenmesi düzensizlikleri, tek bir düzensizlik grubu olarak ele alınmıştır. Hali hazırda istenmeyen düzensizlik olması yanında aynı zamanda Mevzuatta yapılması yasak olan, konsol ucuna kiriş ve kolon eklenmesi durumu da, özellikle 20 yıllık ve daha eski binalarda, ve özellikle kiriş eklenmesi şeklinde, sıkça karşılaşılan bir durum olarak gözlenmiştir.

Şekil 5.'de ise her düzensizliğin yüzde kaç binada görüldüğü gösterilmiştir. Buna göre en çok görülen asma kat ve/ veya yüksek giriş düzensizliği, incelenen binaların \%23'ünde, yan kirişsiz balkon döşeme ve saçak düzensizliği de \%21'inde gözlenmiştir. Asma kat- yüksek giriş düzensizlikleri, hem eski hem yeni binalarda, genellikle yüksek giriş üstüne yapılan çıkmalarla ve giriş kat cephelerinde bölme duvarların kaldırılıp camekânların kullanılması, iç bölümlerinde duvarların direk kaldırılmış olması durumuyla, yani yumuşak kat etkisiyle birlikte görünmektedir. Bu durum özellikle binanın aynı ya da yakın bölgelerinde birçok düzensizliğin bir araya gelmesiyle depremsel davranış açısından daha da kritik bir hal oluşturmaktadır (Koç ve Tuhta, 2012a).

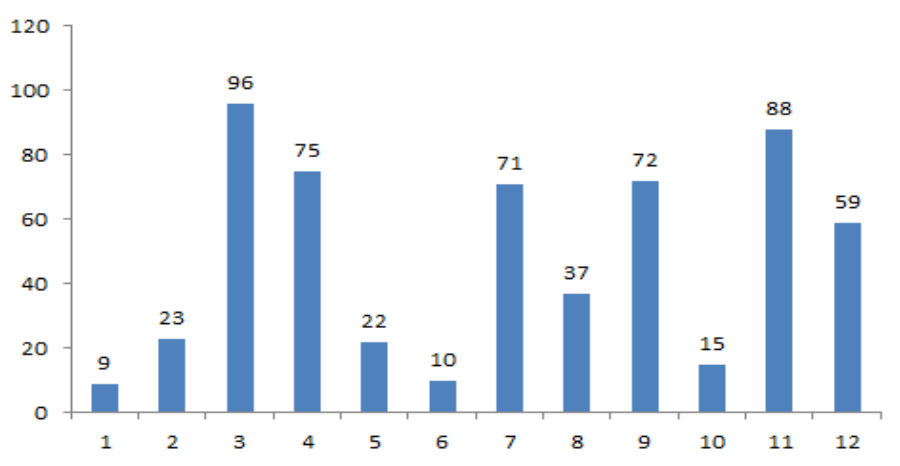

Şekil 4. Düzensizliklerin kendi içindeki yüzde dă̆llımı (Figure 4. Percentage distribution of irregularities within themselves)

\section{Sonuç}

Depremde oluşan kayıplarda, mühendisler gibi mimarların da sorumluluğu büyüktür. Bu durumda, mühendis ve mimarların eksik eğitim almasının da katkısı vardır. $\mathrm{Bu}$ eğitimlerin temel amacı mimar yetiştirmek, diğer amacı ise sorumlu ve bilgili bireyler eğitmektir. Eğitimin nasıl olması gerektiğini de e-ISSN: 2148-2683
Şekil 3. Hangi düzensizliğin kaç binada göründüğü Figure 3.

(Which irregularity is seen in how many buildings)
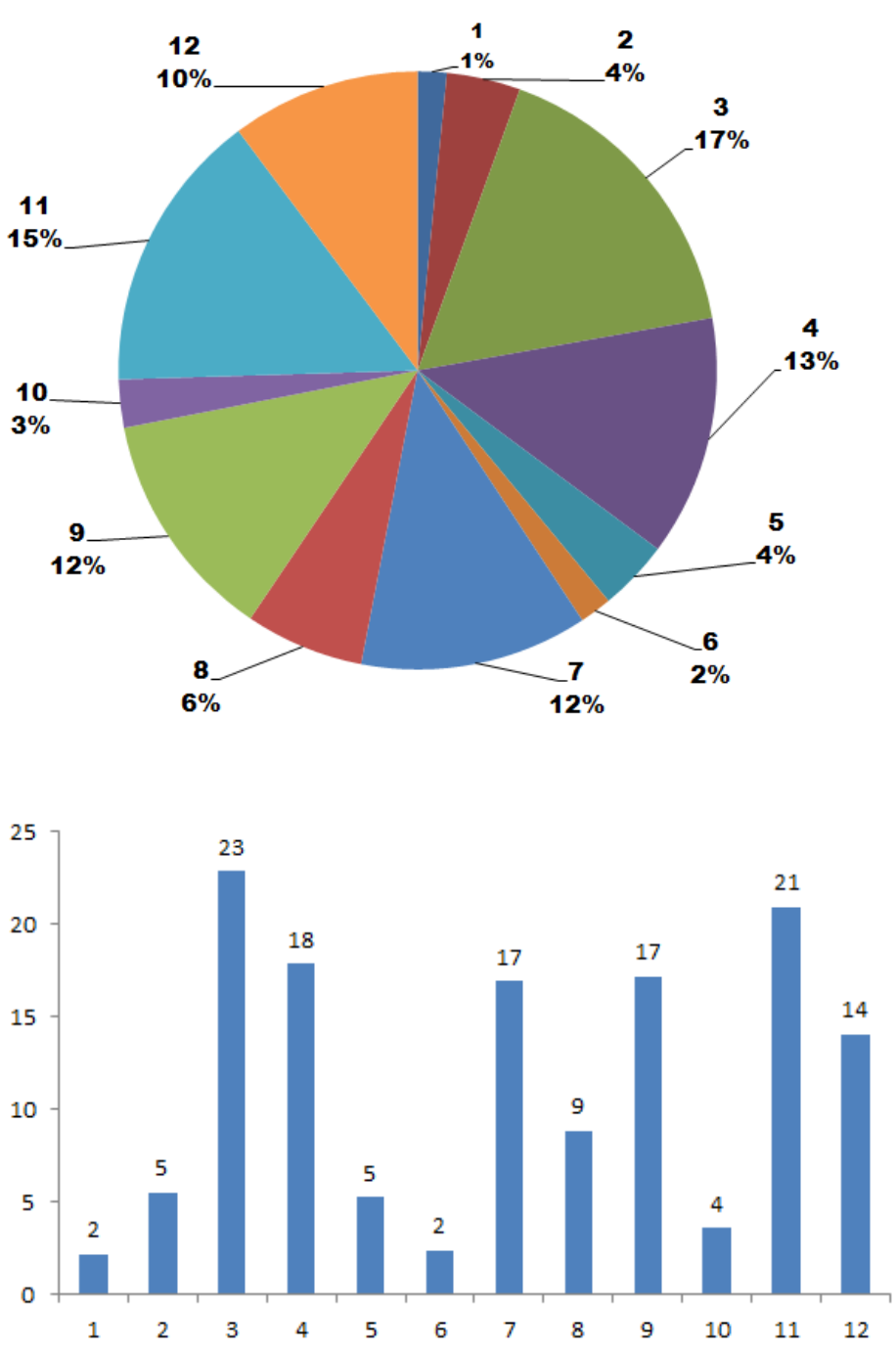

Şekil 5. Her düzensizliğin yüzde kaç binada göründüğ̈̈ (Figure 5. In what percentage of buildings each irregularity appears)

gereksinimler ve sorunlar belirlemektedir. Bina yapım sürecinde inşaat mühendisleri, mimarlar, elektrik mühendisleri ve makine mühendisleri gibi birçok tasarımcı grupları vardır. Bu gruplarda oluşan en ufak bir iletişimsizlik depremin vereceği zarara zemin hazırlar. Sistemlerin birlikte başarılı olabilmesi için disiplinli bir çalışma gereklidir. Gruplar arası iletişimsizlik depreme dayanıklılığın istenilen düzeyde olmamasına sebep olur. Türkiye ve KKTC'de bulunan üniversitelerin "Depreme Dayanıklı Yapı Tasarımı" derslerinin ayrıntılı olarak ele alınması gerekir. Araştırmaların sonucunda üniversitelerde mimarlık hatta kısmen mühendislik bölümlerinde deprem ile ilgili derslerin ayrı dersler olarak yer almadığı görülmektedir (Ayyıldız ve Özbayraktar, 2005). Deprem bölgesinde bulunan ülkemizde 
“deprem” konusuna önem verilmemesi, derslerin yetersiz olması, çok büyük kayıplar oluşturmuştur ve oluşturmaya devam edecektir. Kayıplara yol açmaması için "Depreme Dayanıklı Yapı Tasarımı" dersleri zorunlu hale getirilmeli, lisansüstü programlar önem kazanmalı, uygulamalı olarak eğitim verilmelidir. Eğitimden faydalanırken de teknolojik gelişmelerden geri kalınmamalıdır.

Taşıyıcı sistemde düzensizlik oluşturan bazı durumlar ve taşıyıcı elemanların dayanımını düşüren yanlış uygulamalardan bazıları şu şekilde örneklenebilir: Bodrum katlarının havalandırması vesilesi ile kirişin 50- $60 \mathrm{~cm}$ altında, kolonların arası boş kalacak şekilde yapılan bant pencereler, gerekli önlem alınmazsa, kısa kolon etkisi denilen, kolonun kesme kuvveti etkisiyle güç kaybetmesi duruma yol açar. Ticari amaçlı bölme duvarların kaldırılması da yumuşak kat oluşumuna bağlı olarak toptan göçmeye bile sebep olabilir. Kolon- kiriş sarılma bölgelerinde etriye sıkıştırması yapılmaması, seyrek etriye konulması veya hiç konulmaması da mafsallaşmaya sebep olur. Mafsallaşma, dönmeye izin verilen bağlantı noktalarıdır ve bu noktalarda moment etkisine karşı mukavemet gösterilmez; kısacası dayanım azalır ve binalarda oluşan hasarlar fazlasıyla artmış olur. Beton dayanımının düşük olması da ayrı bir etkendir. Ayrıca beton ile donatının birbirine kenetlenip beraber çalışmaları olan aderans sağlanamaz ise betonarmeden söz etmek söz konusu değildir (Çatal, 2019).

Depreme dayanıksız mimari tasarımların çoğu, temelde rijitlik düzensizliklerinden kaynaklanmaktadır. Bu çalışmada da farklı maddeler olarak özelliklerine göre sinıflandırılan düzensizliklerin çoğu, en temelde rijitlik farklılaşması oluşturan durumlar olarak birleştirilebilir (Koç, 2021d). Rijitlik farklılıkları sadece geometride ve sadece betonarme yapilarda depreme dayanıklı yapı tasarımının bir problemi olarak ortaya çıkmaz. Aynı zamanda malzeme farklılıklarından da oluşabilir ve diğer yapı sistemlerinde de görülebilir (Alpaslan vd., 2015).

Tüm bu temel bilgilerin yanında, yapıda depremsel davranış açısından düzensizlik oluşturabilecek birçok mimari tasarımlar söz konusudur. Mimari tasarımın zorlaması sonucu düzensizliğin taşıyıcı sisteme yansıması, ciddi sorunlara yol açabilir. Bu nedenle günümüzde mimari tercihlerin, taşıyıcı sistemde düzensizlik oluşturmayacak tarzda yapılabilmesi önem kazanmaktadır. Örneğin düzgün bir betonarme taşıyıcı sisteme sahip binaya, ek eleman ankrajları ve cephe kaplamaları ile mimari bir hareket kazandırmak, taşıyıcı sistemi bozarak yapılacak tasarımlardan çok daha tercih edilebilir olmalıdır. Bunun için de, yapı tasarlanırken mimar ve mühendisin birlikte çalışması ve her ikisini de depreme dayanıklı taşıyıcı sistem tasarımı konusunda özümsenmiş üst düzey bilgilere sahip olabilmesi gerekir.

$\mathrm{Bu}$ çalışmada taşıyıcı sisteme yansıyan mimari düzensizliklerin ne oranda kullanıldı̆̆ 1 , örnek bir saha incelemesiyle tespit edilmeye çalışılmıştır. Buna göre 12 grup halinde sınıflandırılmış belli başlı düzensizlikler, incelenen 420 binada şu sıra ve oranlarda görülmüştür:

\section{İncelenen binaların}

\%23'ünde Asma kat ve/ veya yüksek giriş

\% 21 'inde Yan kirişsiz balkon döşeme ve saçaklar

$\% 18$ 'inde Yumuşak kat

\%17'sinde Cephe boşlukları, yatayda- düşeyde asimetri ve/ veya girinti- çıkıntı

e-ISSN: 2148-2683 \%17'sinde Çıkmalı yapıda konsol uç kolon ve/ veya kirişi

\%14'ünde Çıkmalarda çerçeve dışına örülen dış bölme duvarlar1

\%9'unda Bitişik nizam

\%5'inde Süreksiz kiriş - kolon -perde

$\% 5$ 'inde Kisa kolon

\% 4'ünde Saplama kiriş- saplamanın saplaması

$\% 2$ 'sinde Kolon -perde rijitliklerinin planda $\mathrm{x}$ ve y yönünde düzgün dagitılmaması

\%2'sinde Zayıf kolon kuvvetli kiriş etkisi gözlenmiştir.

Çoğu binada aynı zamanda birden çok düzensizlik olduğu için, yüzdelerin kendi içinde toplamı 137 yapmaktadır. Bununla birlikte, süreksiz kiriş- kolon- perde ile kolon -perde rijitliklerinin planda $\mathrm{x}$ ve y yönünde düzgün dagıtılmaması gibi düzensizlikler, sadece gözlemsel inceleme ile tam olarak tespit edilemeyeceğinden, daha detaylı araştırmaların konusu olmalıdır. Ayrıca Bitişik nizam gibi, incelenen alana sıkı şekilde bağlı olan düzensizliklerin oranı hakkında, bu araştırma, kesin bir bilgi vermeyecektir. Kısa kolon, saplama kiriş- saplamanın saplaması, zayıf kolon kuvvetli kiriş düzensizlikleri için de aynı açıklamalar geçerlidir.

\section{Teșekkür}

İnşaat Mühendisleri Oğuzhan Sözkesen, Gökay Hasanoğlu, Arif Acar ve Aziz Kızıltaş'a saha araştırmalarında yaptıkları çalışmalardan dolayı teşekkürlerimi sunarım.

\section{Kaynakça}

Akçaer G., Nur Banu Özdemir N.B., ve Soyluk A. (2015) Depreme dayanıklı yapı tasarımı eğitimi ve mimarlık, 3. Türkiye Deprem Mühendisliği ve Sismoloji Konferansı, 1416 Ekim, DEÜ, İzmir.

Akıncıtürk, N. (2000) Deprem nedeniyle oluşan yapı hasarlarında, yapıların sağlamlaştırılmasında; Mimarın yeri ve görevlerinin incelenmesi, Uludağ Ünv. Müh. Dergisi, Cilt 6 say1 1, s.25- 36 .

Alpaslan E., Hacıefendioğlu K., Birinci F., Kurt M. (2015) Tarihi yapılarda lokal güçlendirmeye bağlı lokal rijitlik artışının yapı davranışına etkisi, 3. Türkiye Deprem Mühendisliği ve Sismoloji Konferansı, 14-16 Ekim, DEÜ, İzmir.

Ayyıldız S., Özbayraktar M. (2005) Mimarlık eğitiminde depreme dayanıklı yapı tasarımı süreci ve bu süreçte disiplinler arası iletişimin önemi, Deprem sempozyumu, Kocaeli, 23- 25 Mart, s. 1224- 1234

Çatal H.H. (2019) Deprem nedeniyle binalarda oluşan hasarlar, 3rd International symposium on innovative approaches in scientific studies, section: Engineering nd natural sciences, April 19- 21, Ankaara, Turkey, s. 310- 315.

Doğan O., Akgül M. (2020) Donatı korozyonunun betonarmenin durabilite ve aderansına etkisi, Anadolu Kongreleri- 5. Uluslararası Uygulamalı Bilimler Kongresi, s. 251- 264.

Koç V., Tuhta S. (2012a) Asma Katlı, Kat Çıkmalı ve Asmolen Döşemeli Yapıların Depremsel Davranışı, Samsun İlinin 
Deprem Riski ve Alınabilecek Önlemler Sempozyumu , 11.05.2012, Ondokuz Mayıs Üniversitesi, Samsun, s. 159173.

Koç V, Tuhta S. (2012b) Depremler Sonrası Zemin Katlarda Görülen Çökmelerin İncelenmesi, Samsun İlinin Deprem Riski ve Alınabilecek Önlemler Sempozyumu 11.05.2012, Ondokuz Mayıs Üniversitesi, Samsun, s. 149- 158.

Koç V. (2016a) Deprem Sonrası Ağır Hasarlı Bina Hasarlarının Sinıflandırılması, Artvin Çoruh Üniversitesi Doğal Afetler Uygulama ve Araştırma Merkezi Doğal Afetler ve Çevre Dergisi, Cilt:2, Say1:1, Ocak, S. 46- 65

Koç V. (2016b) Deprem öncesi ve sonrası gözlenen beton ve donatı korozyonları ile kısa kolon hasarlarının incelenmesi, Avrupa Bilim ve Teknoloji Dergisi, Cilt. 4, No. 7, Haziran, S. $8-20$.

Koç V. (2021a) Taşıyıcı Sistem Tasarım Hatlarına Dair Bir Saha İncelemesi, Mediterranean summit 4th international applied sciences congress, 24- 25 Nisan, Girne, Kıbrıs, s. 105- 113.

Koç V. (2021b) Bina Tipi Yapılarda İstenmeyen Mimari Düzensizliklerin İncelenmesi, İnternational black sea coastline countries scientific research symposium- VI, 2829 Nisan, s. 39- 51.

Koç V. (2021c) Depreme Dayanıklı Yapı Tasarımına Uymayan Binaların Tespiti, Istanbul international modern scientific research congress, 4- 5 Haziran, s. 261- 273.

Koç V., (2021d) Teknoloji ve mühendislik bilimlerine güncel bakış, Bölüm 4, Betonarme binalara etkisi açısından geçmiş depremlerin incelenmesi ve önleme yaklaşımına yönelik olarak yapilmas1 gerekenler, IKSAD Publishing House, Editör:Dr. Öğr. Üyesi Abdul Vahap KORKMAZ, Sayfa sayıs1:230, ISBN:978-625-7562-52-2, Bölüm Sayfaları:101 $-132$

Korkmaz A., Uçar T. (2006) Yumuşak Kat Düzensizliğinin Betonarme Binaların Deprem Davranışında Etkisi, Uludağ Üniversitesi Mühendislik-Mimarlık Fakültesi Dergisi, Cilt 11, Say1 2, s. 65- 76.

Ulusoy Ö., Güven S. (2019) Betonarme yüksek yapıların TDY' ne göre plan düzensizliklerinin örnek yapılarla gözden geçirilmesi, Ç.Ü. Fen ve Müh. Bil. Dergisi, Cilt: 38- 2, s. 514. 